\title{
Effect of different metals on protease activity in sunflower cotyledons
}

\author{
Liliana B. Pena \\ Departamento de Química Biológica \\ Facultad de Farmacia y Bioquímica \\ Universidad de Buenos Aires \\ Junín 956, (C1113AAC) \\ Buenos Aires, Argentina \\ Tel: 541149648237 \\ E-mail: lpena@ffyb.uba.ar \\ María L. Tomaro \\ Departamento de Química Biológica \\ Facultad de Farmacia y Bioquímica \\ Universidad de Buenos Aires \\ Junín 956, (C1113AAC) \\ Buenos Aires, Argentina \\ Tel: 541149648237 \\ E-mail: ptomaro@ffyb.uba.ar

\section{Susana M. Gallego*} \\ Departamento de Química Biológica \\ Facultad de Farmacia y Bioquímica \\ Universidad de Buenos Aires \\ Junín 956, (C1113AAC) \\ Buenos Aires, Argentina \\ Tel: 541149648237 \\ E-mail: sgallego@ffyb.uba.ar
}

Financial support: Grants from the Universidad de Buenos Aires (UBA) and from Consejo Nacional de Investigaciones Científicas y Técnicas (CONICET) (Argentina).

Keywords: Helianthus annuus L., oxidative stress, proteins degradation.

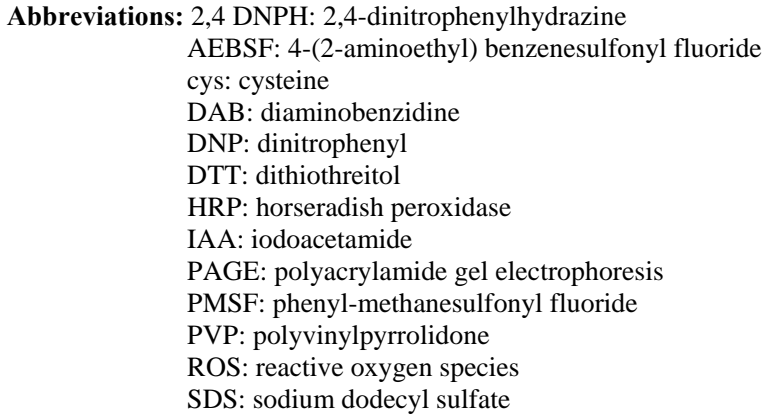

Abbreviations: 2,4 DNPH: 2,4-dinitrophenylhydrazine AEBSF: 4-(2-aminoethyl) benzenesulfonyl fluoride cys: cysteine

DAB: diaminobenzidine

DNP: dinitrophenyl

DTT: dithiothreitol

HRP: horseradish peroxidase

IAA: iodoacetamide

PAGE: polyacrylamide gel electrophoresis

PMSF: phenyl-methanesulfonyl fluoride

PVP: polyvinylpyrrolidone

ROS: reactive oxygen species

SDS: sodium dodecyl sulfate

Proteases are crucial for living cells and play a role in plant cell adaptation to environmental conditions. Oxidative stress produced oxidized proteins which are selectively degraded by proteases. To understand the role of proteolysis in response to metal stress, sunflower plants (a plant suitable for phytoremediation) were treated with $100 \mu \mathrm{M}$ of $\mathrm{CdCl}_{2}, \mathrm{CuCl}_{2}, \mathrm{AlCl}_{3}, \mathrm{CoCl}_{2}$, $\mathbf{P b C l}_{2}, \mathrm{CrCl}_{3}, \mathrm{NiCl}_{2}, \mathrm{HgCl}_{2}$ or $\mathrm{ZnCl}_{2}$. Changes in protease activity, gelatinase profile and protein oxidation were examined in sunflower cotyledons. Our results indicate that this tissue has mainly acid proteases belonging to different classes. Although all metals (except $\mathrm{Zn})$ increased protein oxidation $(62,57,112,74$, 74, 68, 64 and $40 \%$ for $\mathrm{Pb}, \mathrm{Al}, \mathrm{Ni}, \mathrm{Cd}, \mathrm{Hg}, \mathrm{Co}, \mathrm{Cr}$ and $\mathrm{Cu}$ over the control), they altered proteolysis in different ways. $\mathrm{Pb}, \mathrm{Al}$ and $\mathrm{Ni}$ treatment decreased protease activity 22,28 and $30 \%$ respect to control while $\mathrm{Cd}$ and $\mathrm{Hg}$ increased this activity in 23 and $27 \%$. In $\mathrm{Zn}, \mathrm{Cu}$ and $\mathrm{Co}$ treatments protease activity remained similar to control treatment. These results indicate that different proteases are involved in plant defence against metal toxicity. However, the identification of specific

* Corresponding author 
oxidized proteins involved in this process and the metal effect on class specific proteases should provide greater information.

Plant genomes encode hundreds of proteases, but little is know about what roles they play in the life of a plant (Beers et al. 2004). Peptidases are classified based on their catalytic mechanisms. Five catalytic classes (serine, cysteine, aspartic, threonine and metallopeptidases) can been identified within the Arabidopsis genome sequence (Rawling et al. 2004). In general, proteases are thought to be involved in a range of processes, including germination, senescence, defence responses and programmed cell death (Fontanini and Jones, 2002; Segarra et al. 2002; Roberts et al. 2003; Coffeen and Wolpert, 2004). In addition, proteases might also play a role in the plant adaptation to changing environmental conditions. Proteolysis is also associated to oxidative stress promoted by ROS $\left(\mathrm{O}_{2}^{-}, \mathrm{H}_{2} \mathrm{O}_{2}\right.$, $\mathrm{OH})$. The protein modification exerted by oxidative stress is characterized for the production of carbonyl groups in the molecules (Palma et al. 2002).

Sunflower is a plant that dramatically reduces levels of metals in the soil, so it is suitable for phytoremediation (Salt et al. 1995). To understand the role of proteolysis in response to metal stress, sunflower plants were treated with $100 \mu \mathrm{M}$ of different metals. Changes in proteolytic activity, gelatinase profile and protein oxidation have been examined in sunflower cotyledons, a tissue where proteolysis is essential to mobilize protein reserves and thus supplying aminoacids for protein synthesis in developing tissues.

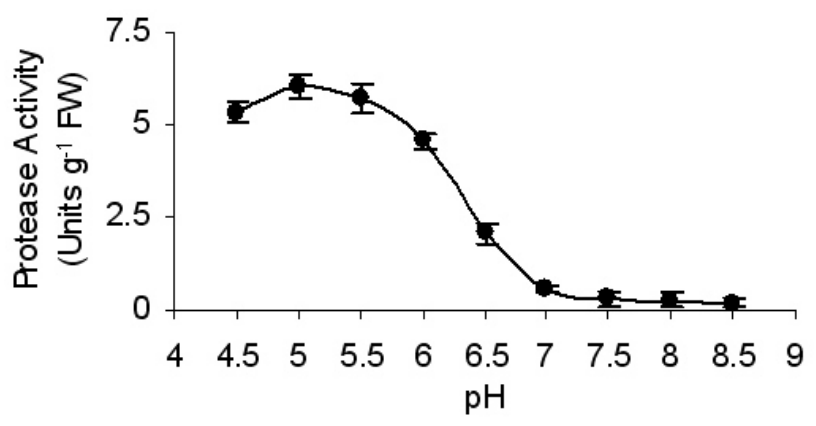

Figure 1. Effect of $\mathrm{pH}$ on the cotyledon protease azocaseinolytic activity. The optimum $\mathrm{pH}$ for the azocasein hydrolysis was determined by measuring its cleavage over the $\mathrm{pH}$ range 4.5-8.5 (100 mM citrate-phosphate-Tris). Activity was defined as the difference in absorbance of the azo-dye released at $340 \mathrm{~nm}$ after $1 \mathrm{hr}$ of incubation $(\mathrm{n}=4)$.

\section{MATERIALS AND METHODS}

\section{Plant material and growing conditions}

Seeds of Helianthus annuus L. (cV Paraiso 20) were germinated in vermiculite and grown in a controlled climate room $\left(24 \pm 2^{\circ} \mathrm{C}, 50 \%\right.$ relative humidity, photoperiod of 16 hrs, light intensity $300 \mu \mathrm{mol} \mathrm{m} \mathrm{m}^{-2} \mathrm{~s}^{-1}$ ). Ten days seedlings were removed from the pots, roots were carefully washed and transferred to separated containers (3 L) for hydroponics, 20 plants per container. The hydroponics medium was half strength Hoagland's nutrient solution (Hoagland and Arnon, 1953) (control) or containing 100 $\mu \mathrm{M}$ of $\mathrm{CdCl}_{2}, \mathrm{CuCl}_{2}, \mathrm{AlCl}_{3}, \mathrm{CoCl}_{2}, \mathrm{PbCl}_{2}, \mathrm{CrCl}_{3}, \mathrm{NiCl}_{2}$, $\mathrm{HgCl}_{2}, \mathrm{ZnCl}_{2}$, (pH 5.8) continuously aerated. After 4 days of treatment cotyledons were used for all further determinations.

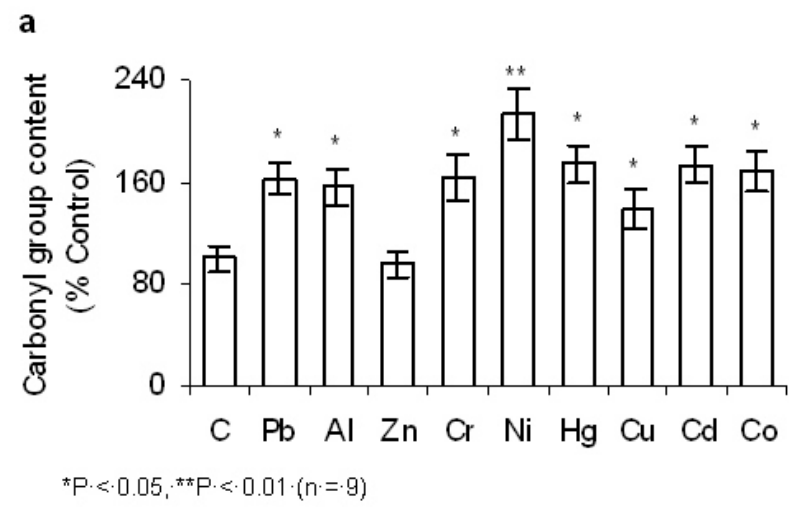

b

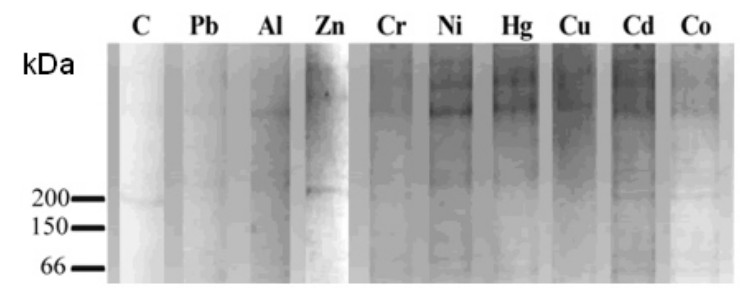

Figure 2. Effect of metals on protein oxidation (a) Total carbonyl groups content $\left(\mathrm{C}=0.83 \mu \mathrm{mol} \mathrm{COOH} \mathrm{mg}^{-1}\right.$ protein).

(b) Extracts derivatized with 2,4 DNPH were separated by SDSPAGE in $12 \% \mathrm{gel}$ and transferred onto nitrocellulose membranes. Derivatized proteins were detected with antibody anti-DNP, bands were visualized as described Material and Methods and photographed with a Fotodyn. Analysis of the image was performed with GelPro software. The positions of molecular mass markers (in kilodaltons) are shown on the left. The electrophoresis and western blot data shown are representative of several experiments.

\section{Protease activity}

Extracts were prepared from $1 \mathrm{~g}$ of cotyledons homogenized in $5 \mathrm{ml}$ of $10 \mathrm{mM}$ buffer phosphate-K $(\mathrm{pH}$ 7.5), $2 \mathrm{mM}$ cys, $5 \mathrm{mM}$ 2-mercaptoethanol, $0.1 \mathrm{~g}$ PVP and $0.1 \%(\mathrm{v} / \mathrm{v})$ Triton $\mathrm{X}-100$ at $4^{\circ} \mathrm{C}$. The homogenates were centrifuged at $10000 \mathrm{~g}$ for $20 \mathrm{~min}$ and the supernatant fraction was used for the assays. Protease activity was measured using azocasein as substrate (Weckenmann and Martin, 1984). Activity was defined as the difference in absorbance of the azo-dye released at $340 \mathrm{~nm}$ after $1 \mathrm{hr}$ of incubation. The optimum $\mathrm{pH}$ for the azocasein hydrolysis was determined by measuring its cleavage over the $\mathrm{pH}$ range 4.5-8.5 (100 mM citrate-phosphate-Tris). To test the 
Effect of different metals on protease activity in sunflower cotyledons

Table 1. Effect of selective proteinase inhibitors and activators on protease activity. Characterization of proteolytic activities at $\mathrm{pH}$ 5.2.

\begin{tabular}{|c|c|c|c|}
\hline \multicolumn{1}{|c|}{ Compound } & Final concentration & Remaining activity (\%) \\
\hline & None (control) & & 100 \\
\hline Methanol (15 $\boldsymbol{\mu l}$ ) & & 103 \\
\hline Inhibitors & PMSF & $100 \mu \mathrm{M}$ & 86 \\
\hline & AEBSF & $100 \mu \mathrm{M}$ & 86 \\
\hline & IAA & $500 \mu \mathrm{M}$ & 39 \\
\hline & E-64 & $5 \mu \mathrm{M}$ & 25 \\
\hline & Pepstain & $20 \mu \mathrm{M}$ & 63 \\
\hline & EDTA & $1 \mathrm{mM}$ & 74 \\
\hline Activators & 0-phenanthroline & $1 \mathrm{mM}$ & 17 \\
\hline & Bestain & $50 \mu \mathrm{M}$ & 78 \\
\hline & DTT & $4 \mathrm{mM}$ & 118 \\
\hline & 2-mercaptoethanol & $2.5 \mathrm{mM}$ & 120 \\
\hline
\end{tabular}

effect of inhibitory or activating compounds, control extracts were preincubated for $30 \mathrm{~min}$ at $40^{\circ} \mathrm{C}$ in the presence of each metals, or in the presence of the following compounds: PMSF, AEBSF, IAA, E-64, EDTA, ophenanthroline, pepstain, bestatin, DTT, 2-mercaptothanol, or cys, after which the substrate was added to start the reaction.

To measure protease activity SDS-gelatin-PAGE was used. Regular SDS-PAGE (Laemmli, 1970) was performed, except that the $10 \%$ resolving gel contained $0.10 \%(\mathrm{w} / \mathrm{v})$ gelatin. Aliquots containing equal protein amount $(50 \mu \mathrm{g})$ were mixed with non-reducing sample buffer $(0.1 \mathrm{M}$ Tris$\mathrm{HCl}, \mathrm{pH} 6.8,2 \%(\mathrm{w} / \mathrm{v}) \mathrm{SDS}, 10 \%$ (v/v) glycerol, $0.01 \%$ (w/v) bromophenol blue). Following electrophoresis at $4^{\circ} \mathrm{C}$, gels were transferred to $1.5 \%(\mathrm{v} / \mathrm{v})$ Triton $\mathrm{X}-100$ in aqueous solution for $1 \mathrm{hr}$ at $20^{\circ} \mathrm{C}$ to allow removal of SDS and renaturation of proteases. Gels were incubated in citrate buffer $100 \mathrm{mM}$ (pH 5.2), $1 \mathrm{mM} \mathrm{CaCl}_{2} 2 \mathrm{~h}$ at $40^{\circ} \mathrm{C}$. Then gels were stained with $0.1 \%$ (w/v) amido black, $40 \%$ (v/v) methanol, $10 \%(\mathrm{v} / \mathrm{v})$ acetic acid for $2 \mathrm{hrs}$ and distained with $40 \%(\mathrm{v} / \mathrm{v})$ methanol, $10 \%(\mathrm{v} / \mathrm{v})$ acetic acid. Protease activity was detected on a dark-blue background as colourless bands.

\section{Proteins and carbonyl groups content}

Protein concentration was determined according to Bradford (1976); bovine serum albumin was used as standard. SDS-PAGE was performed using 12\% (w/v) gel. Proteins were visualized by Coomasie Brilliant Blue R250-staining. Protein oxidation was measured as total carbonyl groups content by their reaction with 2,4 DNPH (Levine et al. 1990). Extracts derivatized with 2,4 DNPH were separated by SDS-PAGE in $12 \%(\mathrm{w} / \mathrm{v})$ gel and transferred onto nitrocellulose membranes. Derivatized proteins were detected with antibody anti-DNP. Bands corresponding to oxidized proteins were visualized using secondary antibodies conjugated with HRP and DAB as substrate.

\section{Statistics}

Values are mean values \pm s.e. Differences among treatments were analyzed by 1-way ANOVA, taking $P<$ 0.05 as significant according to Tukey's multiple range test.

\section{RESULTS AND DISCUSSION}

Protease exhibited high azocaseinolytic activity at acid $\mathrm{pH}$ (maximum between 5.0-5.5) (Figure 1), and optimal temperature occurred between 35 and $45^{\circ} \mathrm{C}$ (data no shown). The characterization of proteolytic activities at $\mathrm{pH}$ 5.2 with class-specific inhibitors revealed that proteases belonging to cysteine, aspartate and metalloprotease groups were detected. These inhibitor studies indicate the involvement of various proteases in cotyledon protein metabolism. Sulphydryl groups protectors activated protease activity (Table 1 ).

Protein carbonylation is an irreversible oxidative process leading to a loss of function of the modified proteins. These oxidized proteins are selectively recognized and degraded by proteolytic enzymes (Palma et al. 2002). Extreme environmental conditions that induce oxidative stress have been associated to an increased carbonyl groups content and to an induction in protease activity. In our experimental condition, although metals produced oxidative stress (except Zn) and increased protein carbonylation (Figure $2 a)$, they had different effect on total protease activity. While $\mathrm{Pb}, \mathrm{Al}$ and $\mathrm{Ni}$ decreased protease activity (22\%, 28\% and $30 \%$ respectively, respect to control values), $\mathrm{Cd}$ and $\mathrm{Hg}$ increased it (23\% and 27\% respectively, over the control values) (Figure $3 \mathrm{a}$ ). $\mathrm{Co}$ and $\mathrm{Cu}$ increased carbonyl groups content (Figure 2a) (68\% and 40\% over the control), however protease activity remained as in control treatments. Some metalloproteinases contain $\mathrm{Zn}$, Co or Mn to activate the water molecule for the hydrolysis of peptide bonds, that is probably why $\mathrm{Zn}$ and Co did not cause modification in protease activity. Metals and auto digestion process themselves had not effect on protease activity (data not shown). Imposition of metals on sunflower plants, 
although altered pre-existing proteases activities (EP1 and EP2), did not induce novel proteases in cotyledons (Figure 3b). Immunodetection of carbonyl residues showed increased oxidation of protein with high molecule weight (Figure 2b). Metal treatments had not significant effect on protein content and profile (Figure 4).

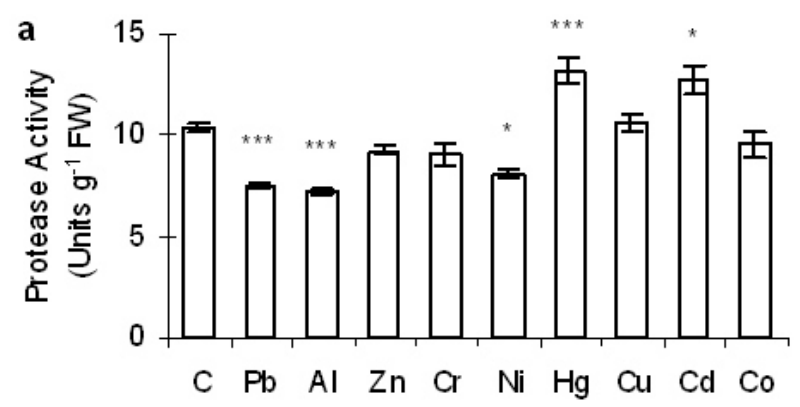

${ }^{*} P<0.05,{ }^{* * *} P<0.001(n=9)$

b C $\mathrm{Pb}$ Al $\mathrm{Zn}$ Cr Ni $\mathrm{Hg} \mathrm{Cu} \mathrm{Cd}$ Co

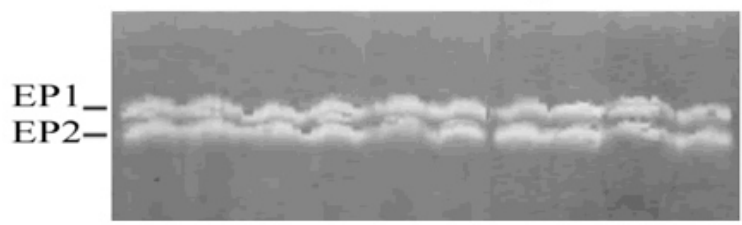

Figure 3. Effect of metals on protease activity. (a) Azocaseinolytic activity was determined spectrophotometrically by following the digestion of azocasein. One unit of enzyme activity was defined as the difference in absorbance of the azo-dye released at $340 \mathrm{~nm}$ after $1 \mathrm{hr}$ of incubation.

(b) Gelatinase profile. Detection of protease activity in SDS-PAGE. Cotyledon extracts (50 $\mu \mathrm{g}$ of total protein) were subjected to SDSPAGE $(10 \%(w / v)$ polyacrylamide, contained $0.10 \%(w / v)$ gelatin). After electrophoresis, gels were incubated in citrate buffer $100 \mathrm{mM}$ $\left(\mathrm{pH} \mathrm{5.2)}\right.$ at $40^{\circ} \mathrm{C}$ overnight. Following incubation, gels were stained with amido black solution. Protease activity was detected on a darkblue background as colourless bands. Gels were photographed with a Fotodyn, analyzed with GelPro software and expressed arbitrary units based on absolute integrated optical density of each band.

In conclusion, sunflower cotyledons have mainly acid protease activity belonging to different classes of proteolytic activities. Degradation of oxidized proteins removes potential toxic fragments and provides aminoacids for new protein synthesis. Metals may affect plant metabolism in different ways. $\mathrm{Pb}, \mathrm{Al}$ and $\mathrm{Ni}$ toxicity mechanism may be attributed to inhibition of protease activity, this seems to be causing carbonylation of proteins. On the other hand, $\mathrm{Cd}$ and $\mathrm{Hg}$ induce oxidative stress and enhance proteolytic activity. Due to $\mathrm{Zn}$ and Co are cofactors of metalloproteases, they have no effect on its activity. These results indicate that different proteases are involved in plant defence against metal toxicity. More studies on the identification of the specific oxidized proteins and the effect of metals on class specific proteases are necessary to improve our knowledge of the mechanisms involved in the different metals toxicity and the possible use of proteases to generate metal tolerant transgenic plants

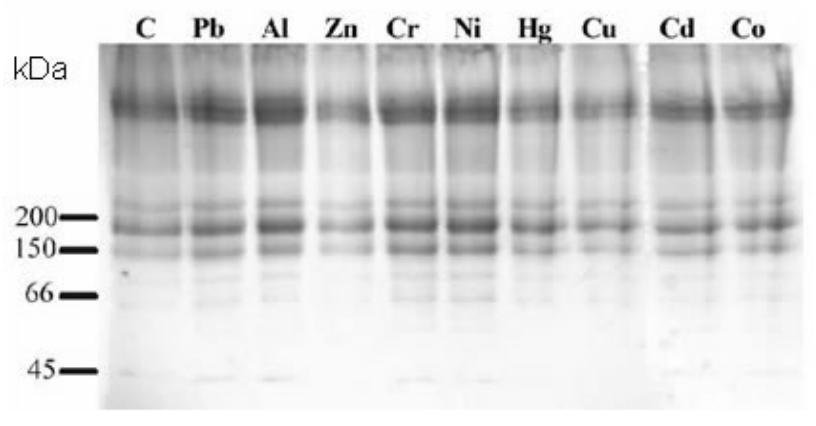

Figure 4. Effect of metals on total proteins. Cotyledon extracts (50 $\mu \mathrm{g}$ of total protein) were subjected to SDS-PAGE (12\% (w/v) polyacrylamide). Proteins were stained with Coomassie Brilliant Blue R-250. The positions of molecular mass markers (in kilodaltons) are shown on the left.

\section{ACKNOWLEDGMENTS}

We thank Myriam S. Zawosnik for critical reading of the manuscript and helpful comments. M.L.T. and S.M.G. are career investigators from CONICET.

\section{REFERENCES}

BEERS, E.P.; JONES A.M. and DICKERMAN, A.W. The S8 serine, C1A cysteine and A1 aspartic protease families in Arabidopsis thaliana. Phytochemistry, January 2004, vol. 65, no. 1, p. 43-58.

BRADFORD, M.M. A rapid and sensitive method for the quantification of microgram quantities of proteins utilizing the principle of protein-dye binding. Analytical Biochemistry, November 1976, vol. 72, no. 1, p. 248-254.

COFFEEN, W.C. and WOLPERT, T.J. Purification and characterization of serine proteases that exhibit caspase-like activity and are associated with programmed cell death in Avena sativa. Plant Cell, April 2004, vol. 16, no. 4, p. 857873.

FONTANINI, D. and JONES, B.L. SEP-1 a subtilisin-like serine endopeptidase from germinated seeds of Hordeum vulgare L cv. Morex. Planta, October 2002, vol. 215, no. 6, p. 885-893.

HOAGLAND, Dennis R. and ARNON, Daniel I. The water culture method for growing plants without soil. Circular 347. Agricultural Experimental Station, University of California. Berkeley. 1953.

LAEMMLI, U.K. Cleavage of structural proteins during the assembly of head of bacteriophage T4. Nature, 1970, vol. 
227, no. 259, p. 680-685.

LEVINE, R.L.; GARLAND, D.; OLIVER, C.N.; AMICI, A.; CLIMENT, I.; LENZ, A.G.; AHN, B.W.; SHALTIEL, S. and STADTMAN, E.R. Determination of carbonyl content in oxidatively modified proteins. Methods in Enzymology, 1990, vol. 186, p. 464-478.

PALMA, J.M.; SANDALIO, L.M.; CORPAS, F.J.; ROMERO-PUERTAS, M.C.; MCCARTHY, I. and DEL RIO, L.A. Plant proteases, protein degradation, and oxidative stress: role of peroxisomes. Plant Physiology and Biochemistry, 2002, vol. 40, no. 6-8, p. 521-530.

RAWLING, N.D.; TOLLE, D.P. and BARRET, A.J. MEROPS: the peptidase database. Nucleic Acids Research, January 2004, vol. 32, Database issue, p. 160-164.

ROBERTS, I.N.; FERNÁNDEZ MURRAY, P.; CAPUTO, C.P.; PASSERON, S. and BARNEIX, A.J. Purification and characterization of a subtilisin-like serine protease induced during the senescence of wheat leaves. Physiologia Plantarum, April 2003, vol. 118, no. 4, p. 483-490.

SALT, D.E.; BLAYLOCK, M.; KUMAR, N.P.B.A.; DUSHENKOV, V.; ENSLEY, B.D.; CHET, I. and RASKIN, I. Phytoremediation: a novel strategy for the removal of toxic metals from the environment using plants. Biotechnology, 1995, vol. 13, no. 5, p. 468-474.

SEGARRA, C.I.; CASALONGUÉ, C.A.; PINEDO, M.L.; CORDO, C.A. and CONDE, R.D. Changes in wheat leaf extracellular proteolytic activity after infection with Septoria tritici. Journal of Phytopathology, March 2002, vol. 150, no. 3, p. 105-111.

WECKENMANN, Dieter and MARTIN, Peter. Endopeptidase activity and nitrogen mobilization in senescing leaves of Nicotiana rustica in light and dark. Physiologia Plantarum, 1984, vol. 60, no. 3, p. 333-340. 